\title{
ЦИФРОВЫЕ ПРАВА В СИСТЕМЕ ГРАЖДАНСКОГО ЗАКОНОДАТЕЛЬСТВА РОССИЙСКОЙ ФЕДЕРАЦИИ
}

\section{DIGITAL RIGHTS \\ IN THE RUSSIAN LAW SYSTEM}

A. Berezina

Summary. This article is devoted to the study of digital rights. A brief overview of digital rights abroad is given. The article examines the Russian legislation, as well as the study of the concept and place of digital rights in the civil law system, the features of digital rights and the scope of their application. The amendments made to the Civil Code of the Russian Federation in 2019 do not give any idea about the essence and specifics of the application of digital rights. A comprehensive analysis of normative acts allows us to establish the actual position of digital rights in the system of civil legislation and to establish the scope and features of their application. This article may be of interest to researchers, postgraduates and students working in the field of mandatory rights.

Keywords: digital rights; utilitarian digital rights; digital financial assets; property rights; obligation right; obligations; objects of civil rights; article 128 of the Civil Code of the Russian Federation; article 141.1 of the Civil Code of the Russian Federation.

\section{பифровые права за рубежом}

3 а рубежом цифровыми правами признаются основные права человека в эру Интернета [17]. Например, права на неприкосновенность частной жизни в Интернете и свободу выражения мнений на самом деле являются продолжением неотъемлемых прав, изложенных во Всеобщей декларации прав человека Организации Объединенных Наций. По данным ООН, отключение людей от Интернета нарушает эти права и противоречит международному праву [прив. по 17]. Цифровыми правами признаются права, которые позволяют людям получать доступ к сети Интернет, создавать и публиковать там произведения, использовать технические средства для доступа в сеть. Такого мнения придерживаются члены английской организации Cyber-Rights \& Cyber-Liberties UK[12] - некоммерческая организация, выступающая за гражданские свободы, основная цель которой - способствовать свободе слова и конфиденциальности в Интернете, повышать осведомленность общественности об этих вопросах. Тема цифровых прав за рубежом очень тесно связана с темой конфиденциальности информации в сети Ин-

\author{
Березина Александра Васильевна \\ Аспирант, Российская академия интеллектуальной \\ собственности (РГАИС), Москва \\ cytron@ya.ru
}

Аннотация. Данная статья посвящена исследованию цифровых прав. Приведён краткий обзор цифровых прав за рубежом. В статье проводится исследование российского законодательства, а также исследование понятия и места цифровых прав в системе гражданского права, особенностей цифровых прав и сферы их применения. Внесённые в 2019 году изменения в Гражданский кодекс Российской Федерации не дают представлений о сущности и специфики применения цифровых прав. Комплексный анализ нормативных актов позволяет установить фактическое положение цифровых прав в системе гражданского законодательства и установить сферу и особенности их применения. Данная статья может быть интересна научным работникам, аспирантам и студентам, работающим в сфере обязательственных прав.

Ключевые слова: цифровые права; утилитарные цифровые права; цифровые финансовые активы; имущественные права; обязательственные права; обязательства; объекты гражданских прав; ст. 128 ГК РФ; ст. 141.1 ГКРФ.

тернет. Большое значение имеет защита и реализация существующих прав, таких как право на неприкосновенность частной жизни и свободу выражения мнения, в контексте цифровых технологий, особенно Интернета. В работе Н. Луччи «Доступ к сетевым услугам и защита конституционных прав: признание важной роли доступа в Интернет для свободы выражения» [15] автор говорит о том, что появление новых средств массовой информации ведёт к проблеме управления информацией, для минимизации чего некоторые страны принимают законодательные меры регулирования цифрового контента. Права человека применяются в Интернете так же, как и в обычной жизни - указано на сайте ООН [16]. Цифровые технологии предоставляют новые средства для осуществления прав человека, но они слишком часто также используются для их нарушения. Особую озабоченность вызывают вопросы защиты данных и конфиденциальности, цифровая идентификация, использование технологий наблюдения, насилие и домогательства в Интернете.

По мнению European Green Party [14] (политическая партия, Брюссель, Бельгия, выступающая за соблюде- 
ние и уважение прав граждан - прим. автора) «Digital rights are civil rights» - цифровые права — это гражданские права. Право на предоставление общего доступа к информации, право на защиту частной жизни, свободу выражения мнений, право на обучение, право на доступ к знаниям, право на собрания или права потребителей являются одними из общих прав, применяемых в цифровом мире, следовательно, они тоже являются цифровыми правами. Некоторые из этих прав приобретают новое значение из-за цифровой среды, в которой они размещены. Этот факт придает этим правам новое значение[13]. Цифровые права - это не что иное, как обычные и общие гражданские права, но выраженные и переведенные в область цифровой сферы. Гражданские права универсальны и, следовательно, должны действовать и в Интернете.

\section{Цифровые права в России}

В Российской Федерации понятие цифровых прав приобрело иное значение.

Федеральный закон [1], введя в гражданский оборот понятие цифровых прав, включил их в число объектов гражданских прав.

Законопроект о внесении изменений в Гражданский кодекс Российской Федерации стал результатом послания Президента Российской Федерации Федеральному Собранию от 15 января 2020 г. о цифровизации. Введению таких объектов в оборот способствовал потенциал электронных денег как нового инструмента экономического развития.

Однако представленный вскоре после этого законопроект не возымел успеха в части введения в оборот цифровых денег, ограничившись лишь введением цифровых прав.

Согласно статье 141.1 ГК РФ цифровыми правами признаются названные в таком качестве в законе обязательственные и иные права, содержание и условия осуществления которых определяются в соответствии с правилами информационной системы, отвечающей установленным законом признакам.

О том, что такое цифровые права из определения введённой нормы не становится ясно. Указанная статья носит бланкетный характер и отсылает к иным нормативным правовым актам. Немного разъяснить данное понятие помог Федеральный закон от 2 августа 2019 г. № 259-Ф3 «О привлечении инвестиций с использованием инвестиционных платформ и о внесении изменений в отдельные законодательные акты Российской Федерации». Осуществляя регулирования отношений в уз- кой, весьма специфической сфере - инвестирования, Закон вводит понятие «утилитарных цифровых прав» и разъясняет его состав.

Статья 8 данного закона так раскрывает понятие утилитарных цифровых прав:

1. право требовать передачи вещи (вещей);

2. право требовать передачи исключительных прав на результаты интеллектуальной деятельности и (или) прав использования результатов интеллектуальной деятельности;

3. право требовать выполнения работ и (или) оказания услуг.

Так же установлено, что эти права могут приобретаться, отчуждаться и осуществляться в инвестиционной платформе, отвечающей определённым признакам, что корреспондирует положениям ст. 141.1 ГК РФ, которая устанавливает общие требования для содержания и условия осуществления этих прав: в соответствии с правилами информационной системы.

Правила закреплены в статье 4 упомянутого закона, они названы правилами инвестиционной платформы. Иных правил пока не предусмотрено.

Исходя из положений части 1 статьи 2 этого закона инвестиционная платформа - информационная система в информационно-телекоммуникационной сети «Интернет», используемая для заключения с помощью информационных технологий и технических средств этой информационной системы договоров инвестирования, доступ к которой предоставляется оператором инвестиционной платформы.

Деятельность по организации привлечения инвестиций заключается в предоставлении оператором инвестиционной платформы доступа к инвестиционной платформе для заключения договора инвестирования лицу, привлекающему инвестиции, или инвестору.

Таким образом, круг цифровых прав ограничивается деятельностью в инвестиционной сфере.

Однако данный закон не ограничивает весь спектр прав, входящих в понятие «цифровых прав». Гражданским кодексом к цифровым правам отнесены также иные права, состав которых до конца не раскрыт. Ясно то, что и иные права должны относиться к имущественным правам, что вытекает из положений статьи 141.1 ГК РФ.

Интересно отметить, что законодатель, поместив цифровые права в один ряд с бездокументарными ценными бумагами (статья 128 ГК РФ), определил место цифровых прав в гражданском праве. Как и бездоку- 
ментарные ценные бумаги, цифровые права закрепляют имущественные права. В пояснительной записке к законопроекту «О внесении изменений в части первую, вторую и четвертую Гражданского кодекса Российской Федерации» указано: «Сущность «цифрового права» как новой юридической фикции близка к сущности ценной бумаги, поэтому под таким правом предлагается понимать совокупность электронных данных (цифровой код, обозначение), которая удостоверяет права на объекты гражданских прав (п. 1 ст. 141.1 ГК). Разумеется, цифровое право может удостоверить лишь права на вещи, иное имущество, результаты работ, оказание услуг, исключительные права [2]. Однако данная редакция статьи 141.1 была отклонена (хотя такое определение «цифровых прав» нам кажется более удачным в гражданско-правовом аспекте). Принятая редакция определяет цифровые права как права.

Следует отметить специфику. Цифровые права имеют определённую особенность: они могут возникать только в децентрализованной информационной системе, в которой должны быть зафиксированы и могут быть реализованы. Пока такой информационной системой служит инвестиционная платформа, используемая в рамках Федерального закона «О привлечении инвестиций с использованием инвестиционных платформ и о внесении изменений в отдельные законодательные акты Российской Федерации». Данная платформа служит местом возникновения и фиксации цифровых прав, а также местом их осуществления. Но это совсем не означает, что при выходе из такой платформы цифровые права исчезнут. Они, фиксируясь в такой системе, существуют объективно и принадлежат конкретному лицу вне зависимости от его местонахождения, но могут быть реализованы только внутри такой платформы, созданной и работающей по определённым правилам.

Уместно также сказать о том, что 1 января 2021 г. внесены новые изменения, которые касаются сферы финансовых активов. Теперь Федеральным законом от 31 июля 2020 г. № 259-Ф3 «О цифровых финансовых активах, цифровой валюте и о внесении изменений в отдельные законодательные акты Российской Федерации» в законодательство вводится понятие цифровых финансовых активов, которые, по сути, и будут фиксироваться с помощи цифровых прав. Цифровыми финансовыми активами признаются цифровые права, включающие денежные требования, возможность осуществления прав по эмиссионным ценным бумагам, права участия в капитале непубличного акционерного общества, право требовать передачи эмиссионных ценных бумаг, которые предусмотрены решением о выпуске цифровых финансовых активов в порядке, установленном настоящим Федеральным законом, выпуск, учет и обращение которых возможны только путем внесения (изменения) записей в информационную систему на основе распределенного реестра, а также в иные информационные системы (п. 2 ст. 1 Закона).

Таким образом, цифровые права закрепляются как имущественные, что обеспечивается их оборотоспособностью.

Вместе с тем, в официальном отзыве на проект федерального закона № 424632-7 «О внесении изменений в части первую, вторую и четвертую Гражданского кодекса Российской Федерации», внесенный депутатами Государственной Думы В.В. Володиным, П.В. Крашенинниковым, А.Г. Аксаковым и другими, принятый Государственной Думой в первом чтении 22 мая 2018 г., отмечено, «Исходя из определения понятия цифровых прав представляется, что такие права фактически являются способом оформления традиционных имущественных прав разной природы (вещные права, обязательственные права, корпоративные права, исключительные права), а также их фиксации и перехода от одного владельца к другому. Однако данные права могут существовать в электронной форме, не создавая при этом новый вид объектов гражданских прав». Целесообразность внесения понятия «цифровые права» была подвергнута критике. Смысл в этом определённый был. Автору статьи представляется нелогичным представление определения «прав» через «права».

Анализируя описанные нормы, видно, что в процессе реализации субъектами своих прав нового объекта права, действительно, не возникает. Как это указано в законе «О привлечении инвестиций с использованием инвестиционных платформ и о внесении изменений в отдельные законодательные акты Российской Федерации» посредством информационной системы реализуются права требования. Федеральный закон «О цифровых финансовых активах, цифровой валюте и о внесении изменений в отдельные законодательные акты Российской Федерации» также называет цифровые права правами требования, то есть в цифровой среде возникают лишь новые объекты прав, такие как запись в распределённом реестре, например.

Отсюда, логичнее было бы предположить введение в качестве объектов гражданских прав не «цифровых прав», а «объектов цифровых прав» или «объектов информационной системы». Такой вывод напрашивается, если вернуться к положениям ст. 128 ГК РФ, где понятия бездокументарная ценная бумага и цифровые права равнозначны в качестве объектов, что приводит к смешиванию объекта права и способа фиксации права, смешение «формы и юридического содержания одного явления». 
Подводя итог вышеизложенному, можно прийти к выводу о том, что цифровые права в системе гражданского законодательства нашли своё место в качестве объектов гражданских прав, имеют природу обязательственных прав, возникают и действуют в информационной среде, представлены в законодательстве двумя федеральными законами. На сегодняшний день цифровые права заключаются в праве требования. Единственной особенностью является их возникновение и осуществление в информационной среде. Иных нормативных правовых актов, регламентирующих иные правомочия в составе цифровых прав, не имеется. Надёжность и удобство принятых изменений будет проверена временем.

\section{ЛИТЕРАТУРА}

1. Федеральный закон от 18.03.2019 № 34-Ф3 «0 внесении изменений в части первую, вторую и статью 1124 части третьей Гражданского кодекса Российской Федерации» (Официальный интернет-портал правовой информации http://www.pravo.gov.ru, 18.03.2019) (дата обращения 15.06.2021).

2. Пояснительная записка к проекту федерального закона «0 внесении изменений в части первую, вторую и четвертую Гражданского кодекса Российской Федерации». http://asozd2c.duma.gov.ru/addwork/scans.nsf/ID/B91DEDFBCF19B4E04325825C0032641E/\%24FILE/424632-7_26032018_424632-7. PDF? OpenElement (дата обращения 17.10.2020).

3. Гражданский кодекс Российской Федерации (часть первая-четвёртая) от 30.11.1994 № 51-Ф3 (ред. от 28.06.2021)//Справочно-правовая система КонсультантПлюс.

4. Проект Федерального закона № 424632-7 «0 внесении изменений в части первую, вторую и четвёртую Гражданского кодекса Российской Федерации» (ред., внесённая в ГД ФС РФ, текст по состоянию на 26.03.2018). URL: https://sozd.duma.gov.ru/bill/424632-7 (дата 0бращения 20.11.2020).

5. Экспертное заключение по проекту федерального закона № 424632-7 «0 внесении изменений в части первую, вторую и четвёртую Гражданского кодекса Российской Федерации» (принято на заседании Совета при Президенте РФ по кодификации и совершенствованию гражданского законодательства 17.01.2019 № 183-1/2019). Справочно-правовая система КонсультантПлюс.

6. Заключение Правового управления по проекту федерального закона № 424632-7 «0 внесении изменений в части первую, вторую и третью Гражданского кодекса Российской Федерации» 19.02.2019. URL: https://sozd.duma.gov.ru/bill/424632-7 (дата обращения 20.11.2020).

7. Официальный отзыв Правительства РФ на проект федерального закона № 424632-7 от 08.06.2018 г., URL: https://sozd.duma.gov.ru/bill/424632-7 (дата обращения 17.10.2019).

8. Гражданское право: Учебник/Под ред. А.П. Сергеева. М.: Проспект, 2021. В 3 т. Т. 1.1040 с.

9. Теория государства и права: Учебник /М.Н. Марченко. М.: Проспект, 2021. 640 с.

10. Алексеев С.С. Общая теория проблем системы советского права. М., 1961.

11. Cardozo journal of international and comparative law. Volume 19, Summer 2011, № 3. URL: https://papers.ssrn.com/sol3/papers.cfm?abstract_id=1756243

12. Cyber-Rights \& Cyber-Liberties UK. URL: https://www.cyber-rights.org/

13. Digital rights are civil rights. Resolution accepted at the 9th EGP Council meeting, Montreuil, Paris, France, 0ctober 9-12, 2008 URL: https://europeangreens. eu/content/digital-rights-are-civil-rights (дата обращения 15.09.2020).

14. European Greens. URL: https://europeangreens.eu/organisation (дата обращения 15.09.2020).

15. Lucchi, Nicola. «Access to Network Services and Protection of Constitutional Rights: Recognizing the Essential Role of Internet Access for the Freedom of Expression». Cardozo journal of international and comparative law. Volume 19, Summer 2011, № 3. URL: https://papers.ssrn.com/sol3/papers.cfm?abstract_ $\mathrm{id}=1756243$. С. 635. (дата обращения 15.09.2020).

16. Office of the Secretary-General's Envoy on Technology. UNO. Ensuring the protection of human rights in the digital era. Report of the Secretary-General Roadmap for Digital Cooperation URL: https://www.un.org/techenvoy/content/digital-human-rights, https://www.un.org/en/content/digital-cooperation-roadmap/ assets/pdf/Roadmap_for_Digital_Cooperation_EN.pdf (дата обращения 29.10.2020).

17. Rosamond Hutt is a Senior Producer at Formative Content. Article: What are your digital rights? https://www.weforum.org/agenda/2015/11/what-are-yourdigital-rights-explainer/\#: : text=Digital\%20rights\%20are\%20basically\%20human, Universal\%20Declaration\%20of\%20Human\%20Rights. (дата 06ращения 15.09.2020).

18. Арямов А.А., Руева Е.О. Цифровое право как объект уголовно-правовой охраны. «Российская юстиция», 2020, № 1 (Справочно-правовая система «КонсультантПлюс», дата обращения 20.11.2020).

19. Винченко Ю.В. Оборотоспособность и правовой режим обектов гражданских прав: соотношение понятий // Известия Иркутской государственной экономической академии. 2013. № 6. С. 118.

20. Дерюгина Т.В., Иншакова А.О. Оборотоспособность и правовой режим объектов гражданских прав: соотношение понятий. Законы России: опыт, анализ, практика. 2019. № 6. (Справочно-правовая система «КонсультантПлюс» дата обращения 09.07.2021).

21. Конобеевская И.М. Цифровые права как новый объект гражданских прав. Изв. Сарат. Ун-та. Нов. сер. Сер. Экономика. Управление. Право. 2019. Т. 19, вып. 3. C. 330-334. D0l: https://doi.org/10/18500?1994-2540-2019-19-3-330-334 (дата обращения 20.11.2020).

22. Эрделевский А.М. 0 цифровых правах. (Справочно-правовая система «КонсультантПлюс» дата обращения 15.10.2019). 